\title{
Land Use Land Cover Classification and Mapping using Geospatial Techniques in Ganderbal District, J \& K, India
}

\author{
Shiba Zahoor ${ }^{*}$, Akhlaq Amin Wani, T. H. Masoodi, M. A. Islam, \\ Asif Ali Gatoo and S. A. Gangoo
}

Faculty of Forestry, Benhama - Ganderbal, SKUAST-K, Shalimar, Srinagar-UT of Jammu and Kashmir, India

*Corresponding author

\begin{abstract}
A B S T R A C T
Keywords

Land use Land

cover,

Remote sensing,

GIS,

Kashmir

Himalayas

Article Info

Accepted:

04 October 2020

Available Online:

10 November 2020

Mapping of land use land cover (LULC) rehearses in the Himalayas is indispensable for sustainable development, planning and management of resources. In light of remote sensing (RS) and geographic information system (GIS) techniques, the study is an endeavor to map LULC patterns of district Ganderbal of Kashmir Himalaya for the year 2018. Images from Landsat-8 (OLI) were used to extricate land cover maps. The study region was delineated through visual image interpretation technique into 10 Landuse/Landcover classes viz, forest, forest scrub, grassland, snow, wasteland, agriculture, TOF, built-up, water body and wetland. LULC map (2018) so generated revealed that among all the LULC classes, forest occupied maximum area of the map i.e. $33.96 \%$ while as wetland with an area of $1.35 \%$ occupied minimum portion of the map. The LULC map was likewise validated using ground truth points. The overall classification accuracy of LULC map came out to be $90.14 \%$ with kappa coefficient of 0.8897 . The outcomes of the study could be used as a spatial standard to illuminate land management and strategy choices made by organizers, specialists, environmentalists and different stakeholders for sustainable LULC management in the district Ganderbal of the Kashmir Himalaya.
\end{abstract}

\section{Introduction}

The capability of satellite based data as a basis for producing significant information for LULC is at this point broadly perceived (Lambin et al., 2003; Yuanet al., 2005; Saadat et al., 2011), albeit starting endeavors were made since mid seventies for application of various interpretation procedures in LULC mapping (Anderson, 1976). The significance of exploring LULC and their effects is a benchmark necessity for sustainable management and planning of natural assets (Read and Lam, 2002). Exact and opportune land cover maps play a vital role in different areas of the developing world including land use planning, food security, modeling of hydrology, and planning and management of natural resources. The investigation of conveyance of land cover is significant for legitimate comprehension of the earth's key qualities and processes, including profitability 
of land, the variety of plant and animal species, and the biogeochemical cycles (Giri, 2012). Foresters use land cover maps to create harvest management plans in a sustainable manner, coordinate biodiversity protection, and take part in climate finance activities like REDD+ (Reducing Emissions from Deforestation and forest degradation and the role of conservation, sustainable management of forests and enhancement of forest carbon stocks) in developing nations (Hall et al., 2011; Potapov et al., 2019).

Land use land cover has been mapped from different sources like geographical maps, soil study associations, and statistical data and so on; yet these are helpful for explicit purposes only and are not truly reliable. However, with the advent of remote sensing technology, every one of these issues have been cleared out beating all the restrictions and have lead to honest and speedy portrayal of the real world in the most ideal manner. The advent of the free U.S. Landsat data strategy, the longest running file, has frequently assisted with catching the most crucial human exercises on the surface of Earth throughout the previous 40 years (Kennedy et al., 2014). Landsat, in terms of frequency and coverage stays an ideal answer for viable capture and evaluation where and when significant natural and human-induced changes have happened, by demonstrating fundamental identification of on-going alterations (Kennedy et al., 2014; Wulder et al., 2015).

The Himalayan region, in spite of being wealthy in terms of biodiversity, has predetermined number of key examinations (Sharma and Chettri, 2005), making it hard to comprehend and likewise plan resource usage, developmental needs, and protection endeavors. This area is frequently viewed as data inadequate with earlier mapping endeavors being irregular, conflicting, and also difficult to reach (Uddin et al., 2014).
Despite the fact that, there has been an expansion in LULC information bases using distinctive remote sensing procedures, there exists incredible variety nearby and scale of study, purpose of mapping, classification plans, types of mapping, and precision appraisal. Sustainable LULC is vital not just for the sustained livelihood of 115 million Himalayan individuals, yet in addition a lot more individuals living in the adjoining IndoGangetic region have been sorely affected due to quickened erosion because of wrong landuse rehearses in the Himalaya (Semwal et al., 2004).

In the present study multi-temporal satellite images of Landsat-8 (OLI) have been utilized to map the LULC classes of district Ganderbal for the year 2018. With expanding scale of human induced change and effects on climate, it has gotten critical to have land assets inventory of the district. There have been restricted endeavors to examine the LULC and inventory of assets in the study region (Mehraj, 2018). Thusly, to address this paucity of LULC baseline data set, the aim of the study is to generate land use land cover map of the Ganderbal district in the state of Jammu and Kashmir, India for the legitimate investigation of land use and its pattern, the reason and its impact on the environment and humanity.

\section{Materials and Methods}

\section{Study area}

The present study was conducted in district Ganderbal of Jammu and Kashmir, India which lies in the central part of Kashmir, situated on the geographical coordinates of $34^{\circ} 08^{\prime} 0^{\prime \prime} \mathrm{N} 74^{\circ} 35^{\prime} 0^{\prime \prime} \mathrm{E}$ to $34^{\circ} 28^{\prime} 0^{\prime \prime} \mathrm{N} 75^{\circ} 30^{\prime} 0^{\prime \prime} \mathrm{E}$ at a normal elevation of 1,619 meters above mean sea level (Figure 1). The region encounters both temperate and sub-alpine conditions and is notable for inordinate yearly 
precipitation of $700 \mathrm{~mm}$ and temperature varying from $5^{0} \mathrm{C}$ to $20^{\circ} \mathrm{C}$. The temperature generally falls underneath freezing point during winter. The relative humidity stays high and differs from $40 \%$ to $86 \%$. Almost $70 \%$ area of the locale is sloping and semihilly covered with green forests and a few areas stay out of reach for a long while during winter. The total geographical area of the locale is 39,304 ha of which 10949 ha area is under forest, 3161 ha of land is under barren and uncultivable land, 5758 ha of land is under non-agricultural use, 1790 ha of land is under grazing and permanent pastures, cultivable waste land is 973 ha and net area sown is 16673 ha (Anonymous, 2011).

Data source: Multi-temporal Landsat-8 (OLI) imageries of 2018, image processing software (ERDAS Imagine) and mapping software (ArcGIS) were utilized for mapping LULC classes of the chosen study area. All the images were taken from NRSC (National Remote Sensing Centre) Hyderabad, India.

\section{Methodology}

The point by point procedure for the study is as per the following:

Procurement of satellite data: Satellite data was acquired from National Remote Sensing Centre (NRSC) Hyderabad.

Pre-processing of satellite data: The satellite data acquired was preprocessed for making a False Color Composite (FCC) with the ideal band combinations by using image processing software. Various image enhancement techniques were additionally used for better interpretation of various Landuse/Landcover (LULC) types in district Ganderbal.

Preliminary survey of the study area: Preliminary review was carried out in the study region to get the prior information about landuse, geology, availability and so forth of various LULC types in Ganderbal district. The data so obtained was valuable in deciding the nature of mapping to be done and the number of LULC classes to be outlined.

Generation of LULC map (2018): Mapping of satellite data was doe through mapping software (ArcGIS) at 1:20000 mapping scale. The satellite data was delineated into various LULC types as follows:

Forest ii. Forest scrub iii. Grassland iv. Agriculture v. Built-up vi. Wetland vii. TOF viii. Water body ix. Snow $x$. Wasteland

Accuracy Assessment of LULC map: The accuracy of LULC map produced was surveyed on the ground through ground truth points. The following information was gathered from the ground truth points for accuracy appraisal:

Latitude ii. Longitude iii. Altitude (m) iv. Agriculture v. Aspect vi. Slope $\%$ vii. Dominant species viii. Village ix. Block $\mathrm{x}$. Tehsil

Validation of LULC map: The producer's accuracy and overall accuracy of the LULC map was generated utilizing error matrix and based on these accuracies KAPPA (khat coefficient) was additionally determined. User's Accuracy is a measure of error of commission and Producer's accuracy is a measure of error of omission. KAPPA analysis is a discrete multivariate technique utilized in accuracy evaluation (Congalton $e t$ al., 1983).

Producer's accuracy $=\frac{\text { No. of correctly classified pixels in each category }}{\text { Total No. of validation points used for that category (column total) }}$

User's accuracy $=\frac{\text { No. of correctly classified pixels in each category }}{\text { Total No. of validation points used for that category (row total) }}$ 
Overall accuracy $=\frac{\text { No. of correctly classified pixels }}{\text { Total No. of validation points }}$

$$
\begin{aligned}
& \mathrm{k}=\frac{\mathrm{N} \sum_{\mathrm{i}=1}^{\mathrm{r}} \mathrm{x}_{\mathrm{ii}}-\sum_{\mathrm{i}=1}^{\mathrm{r}}\left(\mathrm{x}_{\mathrm{i}+} \times \mathrm{x}_{+\mathrm{i}}\right)}{\mathrm{N}^{2}-\sum_{\mathrm{i}=1}^{\mathrm{r}}\left(\mathrm{x}_{\mathrm{i}+} \times \mathrm{x}_{+\mathrm{i}}\right)} \\
& \text { Also, } \mathrm{k}=\frac{\text { Observed accuracy - Chance agreement }}{\text { 1-Chance agreement }}
\end{aligned}
$$

Where, $\mathrm{k}=$ Kappa coefficient

$r=$ number of rows in the error matrix

$\mathrm{N}=$ Number of observations

$\mathrm{x}_{\mathrm{ii}}=$ the number of observations in row and column

$\mathrm{x}_{\mathrm{i}+}=$ total number of observation in row

$\mathrm{x}_{+\mathrm{i}}=$ total number of observation in column

\section{Results and Discussion}

\section{Landuse/Landcover (LULC) of district Ganderbal}

LULC of district Ganderbal for the year 2018 has been presented in Table 1 . Landuse/Landcover map (2018) uncovered that among all the LULC classes, forest occupied maximum area of the map i.e. $33.96 \%$ while as wetland with an area of $1.35 \%$ occupied least portion of the map. Various colors have been allocated to represent different Landuse/Landcover classes in LULC map 2018. Landuse/Landcover map (2018) reveals the area under various LULC classes as shown in Fig. 2. The status of various LULC classes of district Ganderbal in 2018 has been shown in Fig. 1.

\section{Accuracy assessment for validation of LULC map}

Accuracy evaluation was done utilizing ground truth points. A total of 76 ground truth points were taken across the study region for approval of LULC map. Fig. 3 represents the location of ground truth points of LULC map of study area. The error matrix for LULC map (2018) has been presented in Table 3. From error matrix, producers accuracy and users accuracy was determined for each LULC class as demonstrated in Table 3. The overall classification accuracy of LULC map was assessed as $90.14 \%$.

Table.1 Landuse/Landcover of district Ganderbal (2018)

\begin{tabular}{|l|c|c|}
\hline Class & Area (ha) & \% \\
\hline Agriculture & 10703.52 & 7.32 \\
\hline Built-up & 3599.77 & 2.46 \\
\hline Forest & 49689.11 & 33.96 \\
\hline Forest Scrub & 14224.67 & 9.73 \\
\hline Grassland & 15516.19 & 10.60 \\
\hline Snow & 27073.29 & 18.50 \\
\hline TOF & 10382.88 & 7.10 \\
\hline Wasteland & 11042.53 & 7.55 \\
\hline Water body & 2084.00 & 1.43 \\
\hline Wetland & 1979.14 & 1.35 \\
\hline Total & $\mathbf{1 4 6 2 9 5 . 1 0}$ & 100.00 \\
\hline
\end{tabular}


Table.2 Error matrix for LULC map (2018) of district Ganderbal

\begin{tabular}{|c|c|c|c|c|c|c|c|c|c|c|c|}
\hline Class & 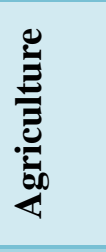 & 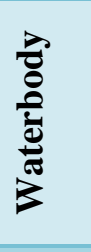 & $\frac{5}{6}$ & 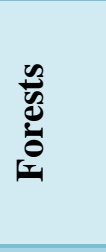 & 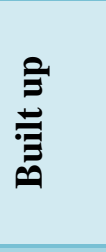 & 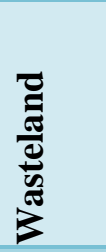 & 总 & है & 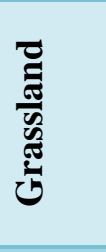 & 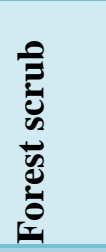 & 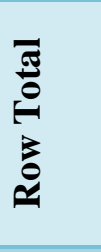 \\
\hline Agriculture & 14 & 0 & 1 & 0 & 1 & 0 & 0 & 0 & 0 & 0 & 16 \\
\hline Waterbody & 0 & 5 & 0 & 0 & 0 & 0 & 1 & 1 & 0 & 0 & 7 \\
\hline TOF & 1 & 0 & 15 & 0 & 0 & 0 & 0 & 0 & 0 & 0 & 16 \\
\hline Forests & 0 & 0 & 0 & 15 & 0 & 0 & 0 & 0 & 1 & 0 & 16 \\
\hline Built up & 1 & 0 & 0 & 0 & 14 & 0 & 0 & 0 & 0 & 0 & 15 \\
\hline Wasteland & 0 & 0 & 0 & 0 & 0 & 14 & 0 & 1 & 0 & 1 & 16 \\
\hline Wetland & 0 & 1 & 0 & 0 & 0 & 0 & 7 & 0 & 0 & 0 & 8 \\
\hline Snow & 0 & 0 & 0 & 0 & 0 & 1 & 0 & 14 & 0 & 1 & 16 \\
\hline Grassland & 0 & 0 & 0 & 0 & 0 & 0 & 0 & 0 & 15 & 1 & 16 \\
\hline Forest scrub & 0 & 0 & 0 & 1 & 0 & 0 & 0 & 0 & 0 & 15 & 16 \\
\hline Column Total & 16 & 6 & 16 & 16 & 15 & 15 & 8 & 16 & 16 & 18 & 142 \\
\hline
\end{tabular}

Table.3 Accuracy assessment for validation of LULC map (2018) of district Ganderbal

\begin{tabular}{|c|c|c|c|c|c|}
\hline Class & Reference totals & Classified totals & Number correct & Producers accuracy & Users accuracy \\
\hline Agriculture & 16 & 16 & 14 & $87.50 \%$ & $87.50 \%$ \\
\hline Waterbody & 6 & 7 & 5 & $83.33 \%$ & $71.43 \%$ \\
\hline TOF & 16 & 16 & 15 & $93.75 \%$ & $93.75 \%$ \\
\hline Forests & 16 & 16 & 15 & $93.75 \%$ & $93.75 \%$ \\
\hline Built up & 15 & 15 & 14 & $93.33 \%$ & $93.33 \%$ \\
\hline Wasteland & 15 & 16 & 14 & $93.33 \%$ & $87.50 \%$ \\
\hline Wetland & 8 & 8 & 7 & $87.50 \%$ & $87.50 \%$ \\
\hline Snow & 16 & 16 & 14 & $87.50 \%$ & $87.50 \%$ \\
\hline Grassland & 16 & 16 & 15 & $93.75 \%$ & $93.75 \%$ \\
\hline Forest scrub & 18 & 16 & 15 & $83.33 \%$ & $93.75 \%$ \\
\hline Totals & 142 & 142 & 128 & & \\
\hline Overall & Classification & Acc & & 90.14 & $\%$ \\
\hline
\end{tabular}


Table.4 Conditional Kappa for each LULC Category

\begin{tabular}{|l|l|}
\hline Class name & Kappa \\
\hline Agriculture & 0.8591 \\
\hline Built-up & 0.7017 \\
\hline Forest & 0.9296 \\
\hline Forest scrub & 0.9296 \\
\hline Grassland & 0.9255 \\
\hline Snow & 0.8602 \\
\hline TOF & 0.8675 \\
\hline Wasteland & 0.8591 \\
\hline Waterbody & 0.9296 \\
\hline Wetland & 0.9284 \\
\hline Overall Kappa Statistics & $\mathbf{0 . 8 8 9 7}$ \\
\hline
\end{tabular}

Fig.1 Status of LULC classes of district Ganderbal (\%) in 2018

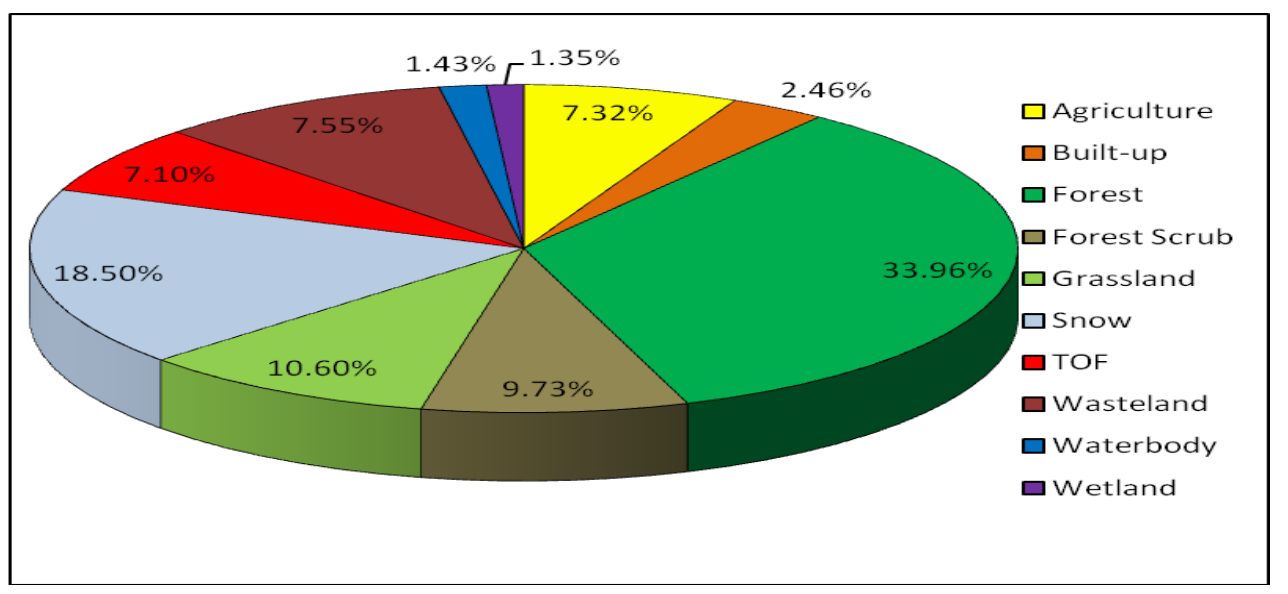

Fig.2 Landuse/Landcover map (2018) of district Ganderbal

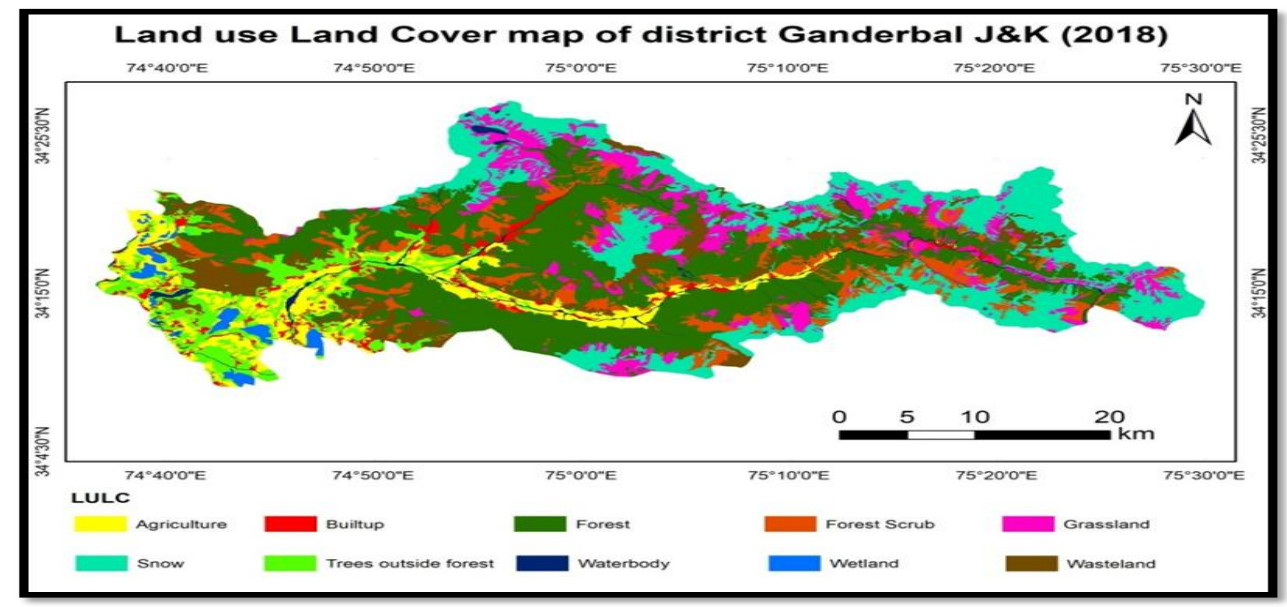


Fig.3 Location of ground truth points (LULC) of district Ganderbal

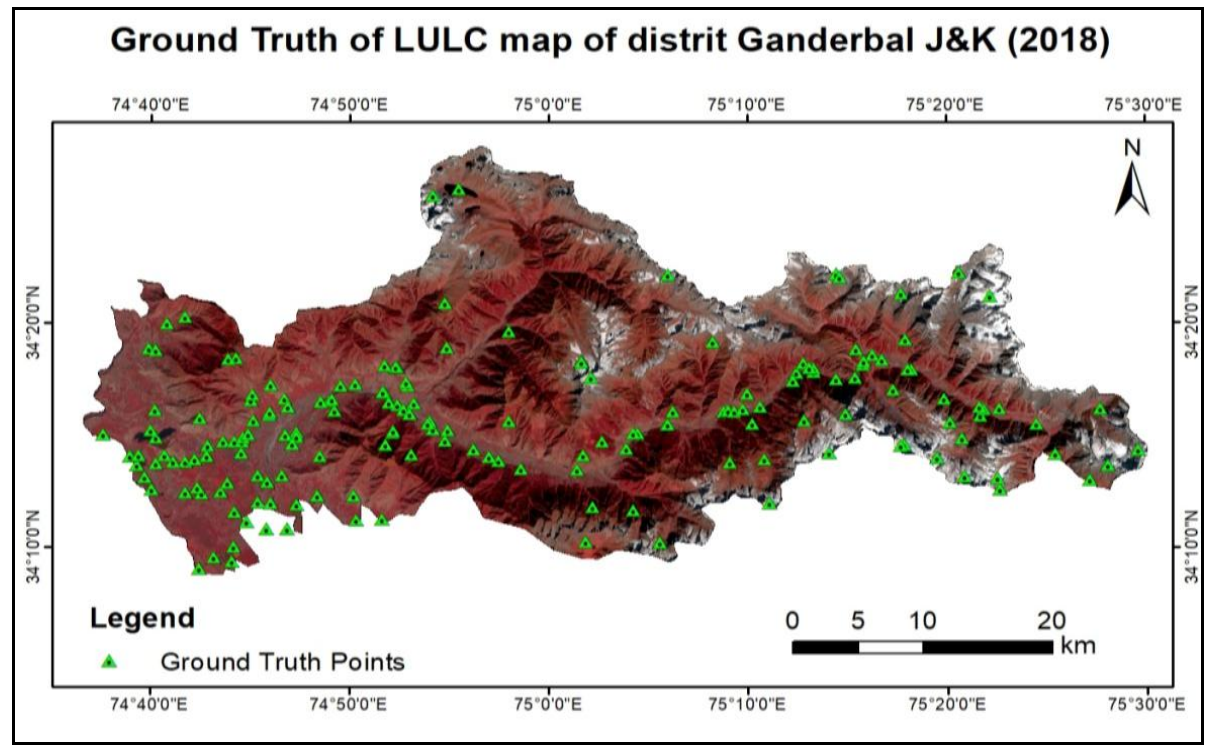

The conditional kappa for each LULC category was determined utilizing kappa coefficient formula. Kappa for forest, TOF and grassland were found to be 0.9296 . The conditional kappa for forest scrub and built up was recorded to be 0.9284 and 0.9255 respectively. For agriculture and snow conditional kappa was found to be 0.8591 . In case of wetland, wasteland and water body, conditional kappa was observed to be 0.8675 , 0.8602 and 0.7017 respectively. The overall kappa statistics was determined as 0.8897 as presented in Table 4.

\section{Landuse/Landcover (LULC) of district Ganderbal}

LANDSAT (OLI) satellite data of 2018 was used to produce Landuse/Landcover map of district Ganderbal in the present study. It was seen that the highest coverage was under forest $(33.96 \%)>$ snow $(18.50 \%)>$ grassland $(10.60 \%)>$ forest scrub $(9.73 \%)>$ wasteland $(7.55 \%)>$ agriculture $(7.32 \%)>$ TOF $(7.10$ $\%)>$ built-up $(2.46 \%)>$ water body $(1.43 \%)$ $>$ wetland (1.35\%) (Fig.4). The mapping was done utilizing ARCGIS mapping software at 1:20000 mapping scale. A number of analysts have carried out investigations on LULC evaluation using various kinds of satellite data, for example, the work led by Kar et al., (2018), Haque and Basak (2017), Pal and Ziaul (2017) and Rawat et al., (2013). Singh et al., (2019) used remote sensing and GIS methods for surveying the area under various land use land cover practices of Medchal district, Telangana, India and found area under agriculture, reserved forest, built up, water body, land without scrub, vegetation and land with scrub to be around $208.8 \mathrm{~km}^{2}$, $26.8 \mathrm{~km}^{2}, 28.12 \mathrm{~km}^{2}, 3.05 \mathrm{~km}^{2}, 42.8 \mathrm{~km}^{2}$, $3.14 \mathrm{~km}^{2}$ and $30.81 \mathrm{~km}^{2}$ respectively. Mehraj (2018) carried out resource mapping and soil quality of trees outside forests (TOF) in Ganderbal district of Jammu and Kashmir and found that among all the LULC classes outlined, forest occupied maximum area $(34.43 \%)$ of the map whereas minimum area was occupied by wetland (1.21\%). Doke (2017) while carrying out LULC mapping of Konkan region, Maharashtra reported that cropland occupied the highest area of 10,814 $\mathrm{km}^{2}(35.17 \%)$ of the total area whereas the lowest area of $678 \mathrm{~km}^{2}$ (2.18\%) was occupied by settlement. A number of researchers in the past have likewise used LANDSAT 8 
imageries to generate LULC maps which include the study conducted by Rwanga and Ndambuki (2017) while carrying out the LULC mapping of Limpopo province, South Africa and Francis et al., (2017) who assessed temporal and spatial forest cover changes in Udupi district of Karnataka between the years 1973 to 2016.

\section{Accuracy assessment and conditional kappa}

In the present study, the overall classification accuracy of LULC map came out to be 90.14 $\%$ with overall kappa statistics of 0.8897 (Fig. 4). The Tewabe and Fentahun (2020) detected land use and land cover change using remote sensing in the Lake Tana Basin, Northwest Ethiopia. They observed that overall accuracy in the basin was $84.21 \%, 83.32 \%$ and $91.40 \%$ and kappa coefficient of $79.02 \%, 83.32 \%$, $89.66 \%$ for the years 1986, 2002 and 2018 respectively.

Traore et al., (2020) while investigating land use/land cover change of Bangui city, Central Africa got overall accuracies and overall Kappa statistics of $92.5 \%, 82.5 \%$ and $87.5 \%$, and $0.90,0.87$ and 0.83 for 1986,1999 and 2018 images, respectively. Islam et al., (2018) while working on the land use classification of Chunati wildlife sanctuary, Bangladesh obtained an overall classification accuracy of $92.16 \%$ for 2015 data, $86.15 \%$ for 2010 , and $83.96 \%$ for 2005 with Kappa values of 0.89 , 0.82 , and 0.81 for 2015, 2010, and 2005 respectively. Chakraborty et al., (2016) used Landsat images for the years 1990, 1999, 2009 and 2014 for mapping land use and land cover change in the central Himalayan region and obtained overall accuracies of $82 \%, 87 \%$, $87 \%$ and $88 \%$ for 1990, 1999, 2009 and 2014, respectively. The findings of our study are also in agreement with Rwanga and Ndambuki (2017), Wani et al., (2014) and Moskal et al., (2011).
In conclusion the present investigation evaluated and mapped different LULC classes in the Ganderbal district of Kashmir Himalaya using Landsat-8 OLI data for the year 2018. The outcomes revealed that the significant land use in the district was forestry followed by snow.

The results of present study would eventually assist in recognizing and assessing the restricted land use land cover classes and also the environmentally critical areas which can be delimited as problem areas for protection or remediation. The assessment of LULC practices would likewise help in comprehending the effects of different developmental exercises on these land cover resources from one perspective and planning process on the other. Thusly, we expect that the finding of this study have significant policy implications for the sustainable land use land cover practices in the Kashmir Himalayas.

\section{Acknowledgement}

We are highly thankful to the Department of Science and Technology, Government of India for financial support under INSPIRE Fellowship no. DST/INSPIRE Fellowship/ 2018/IF180413.

\section{References}

Anderson, J. R. 1976. A land use and land cover classification system for use with remote sensor data (Vol. 964). US Government Printing Office.

Anonymous. 2011. Census of India. A - 5 State Primary Census Abstract, India.

Chakraborty, A., Sachdeva, K. and Joshi, P. K. 2016. Mapping long-term land use and land cover change in the central Himalayan region using a tree-based ensemble classification approach. Applied Geography, 74: 136-150.

Chen, J., Chen, J., Liao, A., Cao, X., Chen, L. 
and Chen, X. 2015. Global land cover mapping at $30 \mathrm{~m}$ resolution: A POKbased operational approach. ISPRS Journal of Photogrammetry and Remote Sensing. $\quad$ http://dx.doi.org/10.1016/ j.isprsjprs.2014.09.002.

Congalton, R.G., Oderwald, R.G. and Mead, R.A. 1983. Assessing Landsat classification accuracy using discrete multivariate statistical techniques. Photogrammetric Engineering and Remote Sensing49(12): 1671-1678.

Doke, B. A. 2017. Land Use/Cover Mapping of Konkan Region, Maharashtra. International Journal of Current Research 9(10): 1-6.

Francis, R. Pruthviraj, U. and Shetty, A. 2017. Temporal forest cover analysis of Udupi district in Karnataka using remote sensing and GIS. International Journal of Engineering Research in Electronics and Communication Engineering 4(5): 59-64.

Giri, C. P. 2012. Remote Sensing of Land Use and land Cover: Principles and Applications. Series in Remote Sensing Applications. Taylor \& Francis, UK.

Hall, D., Hirsch, P. and Li, T. M. 2011. Introduction to Powers of Exclusion: Land Dilemmas in Southeast Asia. Singapore: National University of Singapore Press; Honolulu, HI: University of Hawaii Press.

Haque, M. I. and Basak, R. 2017. Land cover change detection using GIS and remote sensing techniques: A spatio-temporal study on Tanguar Haor, Sunamganj, Bangladesh. The Egyptian Journal of Remote Sensing and Space Sciences 20: 251-263.

Islam, K., Jashimuddin, M., Nath, B. and Nath, T. K. 2018. Land use classification and change detection by using multi-temporal remotely sensed imagery: The case of Chunati wildlife sanctuary, Bangladesh. The Egyptian Journal of Remote Sensing and Space Sciences 21: 37-47.

Kar, R., Obireddy, G. P., Kumar, N. and Singh, S. K. 2018. Monitoring spatio-temporal dynamics of urban and peri-urban landscape using remote sensing and GISA case study from Central India. The Egyptian Journal of Remote Sensing and Space Sciences30: 1-11.

Kennedy, R. E., Andr, S., Cohen, W. B., Gomez, C., Griffiths, P. and Hais, M.2014. Bringing an ecological view of change to Landsat-based remote sensing. Frontiers in Ecology and the Environment, $12 . \quad 339 \mathrm{e} 346$. http://dx.doi.org/ 10.1890/130066.

Lambin, E. F., Geist, H. and Lepers, E. 2003. Dynamics of land use and cover change in tropical regions. Annu. Rev. Environ. Resour. 28: 205-241.

Mehraj, B. 2018. Resource mapping and soil quality assessment of trees outside forests (TOF) in Ganderbal district of Jammu and Kashmir. M. Sc. Thesis. Sher-e-Kashmir University of Agricultural Sciences and Technology, Kashmir, India.

Moskal, L. M., Styers, D. M. and Halabisky, M. 2011. Monitoring urban tree cover using Object-Based Image Analysis and public domain remotely sensed data. Remote Sensing3: 2243-2262.

Pal, S. and Ziaul, S. 2017. Detection of land use and land cover change and land surface temperature in English Bazar urban centre. The Egyptian Journal of Remote Sensing and Space Sciences 20: 125-145.

Potapov, P., Tyukavina, A., Turubanova, S., Talero, Y., Hernandez-Serna, A., Hansen, M., et al., (2019). Annual continuous fields of woody vegetation structure in the lower mekong region from 2000-2017 landsat time-series. Remote Sens. Environ. 232:111278. doi: 10.1016/j.rse.2019.11 1278.

Rawat, J. S., Biswas, V. and Kumar, M. 2013. Changes in land use/cover using geospatial techniques: A case study of Ramnagar town area, district Nainital, Uttarakhand, India. The Egyptian Journal of Remote Sensing and Space Sciences 16: 111-117.

Read, J. M. and Lam, N.S. N. 2002. Spatial methods for characterising land cover and detecting land-cover changes for the 
tropics. Int. J. Remote Sens. 23(12): 2457- 2474. https://doi.org/10.1080/01431160110106 140.

Rwanga, S. S. and Ndambuki, J. M. 2017. Accuracy assessment of land use/land cover classification using Remote Sensing and GIS. International Journal of Geosciences8: 611-622.

Saadat, H., Adamowski, J., Bonnell, R., Sharifi, F., Namdar, M., Ale-Ebrahim, S., 2011. Land use and land cover classification over a large area in Iran based on single date analysis of satellite imagery. ISPRS J. Photogrammetry Remote Sens. 66, 608-619.

Semwal, R., Nautiyal, S., Sen, K.K., Rana, U., Maikhuri, R.K., Rao, K. S. and Saxena, K. G. 2004. Patterns and ecological implications of agricultural land-use changes: a case study from central Himalaya, India. Agric. Ecosyst. Environ. 102(1): 81-92.

Sharma, E. and Chettri, N. 2005. ICIMOD's transboundary biodiversity management initiative in the Hindu KusheHimalayas. Mountain Research and Development, 25. $278 \mathrm{e} 281$.

Singh, K., Reddy, M. A. and Kumar, B. 2019. Remote Sensing and Gis Based Land Use and Land Cover Information of Medchal Mandalof Medchal District. International Journal of Engineering and Advanced Technology, 9(2): 2249 - 8958.

Tewabe1, D. and Fentahun, T. 2020. Assessing land use and land cover change detection using remote sensing in the Lake Tana
Basin, Northwest Ethiopia. Cogent Environmental Science, 6(1): 1778998, DOI: 10.1080/23311843.2020.1778998.

Traore, M., Ndepete, C. P., Guerembo, R. L. Z. and Pour, A. B. 2020. Assessment of land use/land cover change mapping in Bangui city using remote sensing and GIS techniques. The International Archives of the Photogrammetry, Remote Sensing and Spatial Information Sciences, 63.

Uddin, K., Shrestha, H. L., Murthy, M., Bajracharya, B., Shrestha, B. and Gilani, H. 2014. Development of 2010 national land cover database for the Nepal. Journal of Environmental Management, $1 \mathrm{e} 9$.

Wani, A. A., Joshi, P. K. and Singh, O. 2014. Mapping agroforestry cover and trend in the southern region of Kashmir Himalayas using remote sensing and GIS. $3^{\text {rd }}$ Jammu and Kashmir Agricultural Science Congress, 12-14 May 2014, SKUAST-Kashmir, J\&K, India.

Wulder, M. A., White, J. C., Loveland, T. R., Woodcock, C. E., Belward, A. S. and Cohen,W. B. 2015. The global Landsat archive: Status, consolidation, and direction. Remote Sensing of Environment.http://dx.doi.org/10.1016/ j.rse.2015.11.032.

Yuan, F., Sawaya, K. E., Loeffelholz, B. and Bauer, M. E. 2005. Land cover classification and change analysis of the Twin Cities (Minnesota) Metropolitan Area by multitemporal Landsat remote sensing. Remote Sens. Environ. 98: 317328.

\section{How to cite this article:}

Shiba Zahoor, Akhlaq Amin Wani, T. H. Masoodi, M. A. Islam, Asif Ali Gatoo and Gangoo, S. A. 2020. Land Use Land Cover Classification and Mapping using Geospatial Techniques in Ganderbal District, J \& K, India. Int.J.Curr.Microbiol.App.Sci. 9(11): 3838-3847. doi: https://doi.org/10.20546/ijcmas.2020.911.459 